\title{
Phenomenological Effects of Solvent-Casting Conditions on Pore Characteristics of Regenerated Cellulose Membranes
}

\author{
Hideki IIJIma, ${ }^{\dagger}$ Michitaka Iwata, ${ }^{*}$ Miki Inamoto, and Kenji KamidE** \\ Fundamental Research Laboratory of Natural and Synthetic Polymers, \\ Asahi Chemical Industry Co., Ltd., \\ 11-7 Hacchonawate, Takatsuki, Osaka 569, Japan \\ * Technology Development Section, Hollow Fiber Plant, Asahi Chemical Industry Co., Ltd., \\ 4-3400-1 Asahi-machi, Nobeoka, Miyazaki 882, Japan \\ ** Laboratory of Clothing, Faculty of Education, Kumamoto University, \\ Kurokami 2-40-1, Kumamoto 860, Japan
}

(Received August 6, 1996)

\begin{abstract}
An attempt was made (1) to prepare porous regenerated cellulose membranes by casting cellulose cuprammonium solutions and then immersing them into aqueous acetone solutions as coagulant, and (2) to investigate membrane characteristics such as radius of secondary particles $S_{2}$ on the surfaces of the membranes, mean pore diameter measured by the water-flow-rate method $2 r_{\mathrm{f}}$, membrane porosity by apparent density method $\operatorname{Pr}\left(\mathrm{d}_{3}\right)$, and membrane thickness of dry membrane $L_{\mathrm{d}}$, and (3) to clarify phenomenological effects of solvent-casting conditions on pore characteristics of the membrane formed and to explain the effect in terms of the particle growth theory proposed previously by Kamide-Iijima et al. (KI). Surfaces of membranes prepared by immersing cast solutions in coagulation solution having weight fraction of acetone $w_{\text {Acetone }}$ below 0.30 consisted of the secondary particles of polymer-rich phase (referred to as "polymer particle"). As the ammonia concentration in the system was higher, polymer particles of polymer-rich phase grow faster; ammonia was one of the most important factors dominating the size of polymer particles, composing the membranes. $L_{\mathrm{d}}$ was in proportion to the cellulose weight fraction $w_{\text {Cell }}$ of cast solutions; on the contrary, $\operatorname{Pr}\left(\mathrm{d}_{3}\right)$ and $2 r_{\mathrm{f}}$ were inversely proportional to $w_{\text {Cell }}$. These experimental findings suggest strongly that density of dried polymer particles increases in proportion to $w_{\text {Cell }}$ in the solutions. Pore shape in a whole body of a membrane changed drastically from noncircular pores to circular pores when $w_{\text {Acetone }}$ in coagulation solutions exceeded 0.30 , indicating that $w_{\text {Acetone }}$ dominates phase separation conditions such as phase volume ratio $R\left(\equiv V_{(1)} /\right.$ $V_{(2)} ; V_{(1)}$ and $V_{(2)}$ are volumes of polymer-lean and -rich phases, respectively), compositions of phase separation points. Changes in $\operatorname{Pr}\left(\mathrm{d}_{3}\right), 2 r_{\mathrm{f}}$ and tensile strength $T S$ of the membranes, prepared by using coagulation solutions having different $w_{\text {Acetone }}$, coincide fairly well with that of pore shape. Membranes constructed by larger cellulose particles have larger pores, and this tendency agreed well with results obtained by KI's lattice theory on pore size distribution proposed before. KEY WORDS Cuprammonium Cellulose / Porous Polymeric Membrane / Phase Separation Method / Pore Characteristics / Acetone / Particle Growth /
\end{abstract}

Among numerous methods proposed hitherto for preparing porous polymeric membranes such as solvent casting method, radiation track-etching method, stretching method, and sintering method, the solvent casting method is a method for vast technological importance, as it enables us to produce membranes with a huge range of mean pore size. In the solvent casting method, polymer solution cast on a flat glass plate is phase-separated into polymer-rich and -lean phases by evaporating good volatile solvent from the solution or by immersing the cast solution into coagulation solution containing nonsolvent. Kamide et al. ${ }^{1}$ noticed an important role of "particle growth concept" in membrane formation mechanism in the solvent casting method (i.e., the phase separation method).

Recently, Kamide-Iijima and their collaborators $(\mathrm{KI})^{2-7}$ reported, based on their "particle growth concept," some theoretical studies as well as computer experiments on both the mechanism of formation of porous polymeric membranes prepared by the phase separation method and the characteristics of their membrane structure. The detailed steps of the formation of polymeric membranes by the phase separation method are illustrated in Figure 1: If the initial polymer volume fraction $v_{\mathrm{p}}^{0}$ is less than the polymer volume fraction at a critical solution point $v_{\mathrm{p}}^{\mathrm{c}}$, the polymer-rich phase separates first as nuclei (steps a and b in Figure 1), which grow to the primary particles (steps b- $d$ in Figure 1), ${ }^{3}$ and the primary particles amalgamate into the secondary particles (steps $\mathrm{d}-\mathrm{f}$ in Figure 1). ${ }^{4}$ In the subsequent steps, the secondary particles contact with each other to form gel membranes, which become dried membrane through desolvation and drying (steps $\mathrm{g}$ - j in Figure 1).

For the latter steps (steps $\mathrm{g}$ - $\mathrm{j}$ in Figure 1), KI derived equations giving pore size distribution $N(r)(r$, radius of pore) and porosity $\mathrm{Pr}$ as functions of phase volume ratio $R\left(\equiv V_{(1)} / V_{(2)} ; V_{(1)}\right.$ and $V_{(2)}$ are volumes of polymerlean and -rich phases, respectively) and radius of secondary particles $S_{2} \cdot{ }^{5}$ Furthermore, they clarified by computer simulation experiments ${ }^{6}$ the applicability limits of the above theoretical equation of $N(r)$ to practice and the effects of the structural contraction occurred, more or less, during the coagulation process (steps $\mathrm{f}-\mathrm{h}$ in Figure 1) on the resultant dry membrane structure.

For preparation of porous polymeric membranes by the phase separation method, it is necessary that liquidliquid two-phase separation occurs in a system of poly$\mathrm{mer} /$ solvent/nonsolvent. From view point of manufac- 


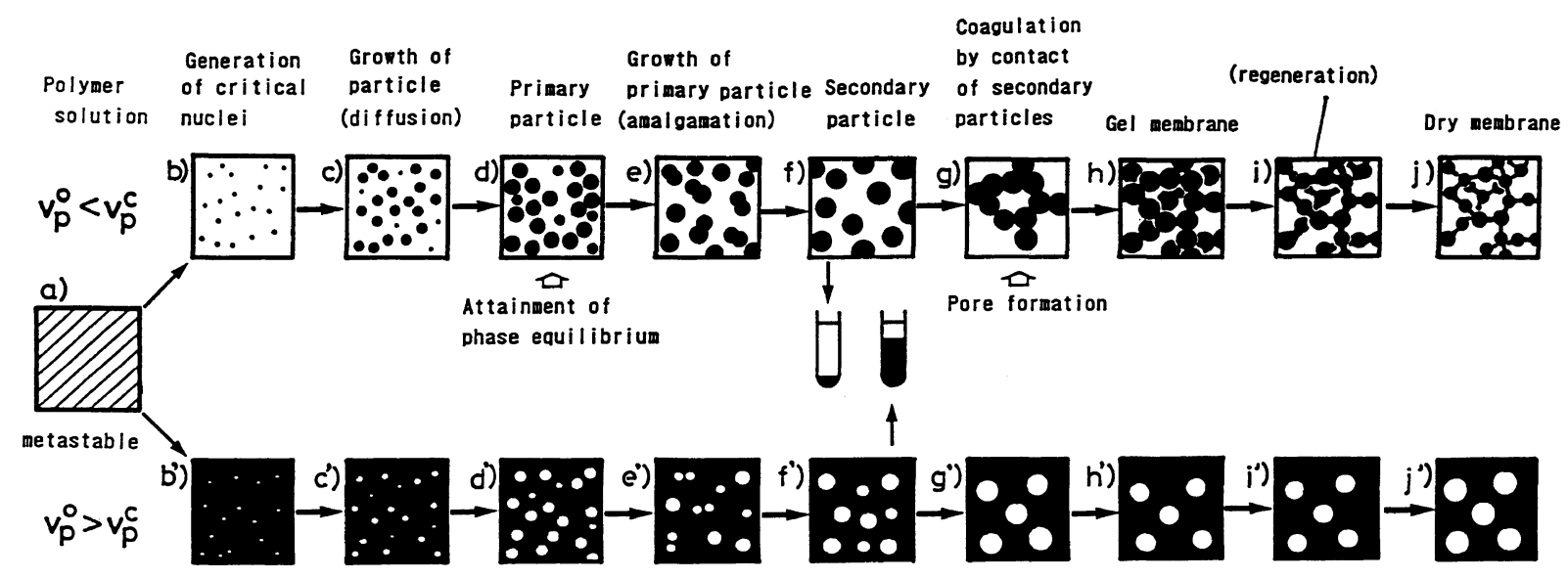

Figure 1. Elementary steps in porous polymeric membrane formation by the phase separation method: $v_{\mathrm{p}}^{0}$, initial polymer volume fraction of the solution when the phase separation occurs; $v_{\mathbf{p}}^{\mathrm{c}}$, polymer volume fraction at the critical solution point.

turing polymeric membranes in an industrial scale, it is desirable for polymers to dissolve a single solvent or a simple mixture of solvents, because of the easiness of manufacturing.

Cellulose has been regarded as improper material for preparing porous membranes by the liquid phase separation method, because it does not dissolve, without exception, in a single solvent or a mixture of solvents without formation of solvation or metal complexes. ${ }^{8}$ In the latter case, the compositions of cellulose solution (for example, cuprammonium solution ${ }^{9}$ ) are extremely complicated. Until recently, no one knew that truly liquidliquid two-phase separation occurs in the system of cellulose solution and nonsolvent. Accordingly, a rather complicated method has been proposed in patent literatures to produce porous cellulose membranes with mean pore diameter of $0.2-3.0 \mu \mathrm{m}$ : For example, in the first step, porous cellulose acetate membranes or porous cellulose nitrate membranes are prepared by the phase separation method, and then they are saponified with aqueous sodium hydroxide solution ${ }^{10}$ to convert cellulose derivatives to cellulose. Another example is emulsion method ${ }^{11}$ where polyethylene oxide is mixed with cuprammonium cellulose solution, but by this method it is difficult to form through-pores with high pore density and also with enough strength of the membrane.

In 1981, Iwata et al. ${ }^{12}$ discovered empirically that acetone is suitable as nonsolvent which causes liquidliquid two-phase separation in cuprammonium cellulose solution, and based on their discovery, porous regenerated cellulose membranes with the mean pore diameter as measured by the water-flow-rate method $2 r_{\mathrm{f}}$ ranging from $15 \mathrm{~nm}$ to $1 \mu \mathrm{m}$ have been commercially produced. KI confirmed the growth of the primary particles to the secondary particles in the above system of cuprammonium cellulose solution/acetone/water. ${ }^{4}$

In this article, we attempted to investigate in a systematic manner phenomenological effects of solvent-casting conditions (i.e., the weight fractions of acetone $w_{\text {Acetone }}$ and ammonia $w_{\mathrm{NH}_{3}}$ in the coagulation solution, and the weight fractions of cellulose $w_{\text {Cell }}$ and ammonia $w_{\mathrm{NH}_{3}}$ in the cast solution) on the pore characteristics of the resultant membranes such as radius of the secondary particles $S_{2}$ existing on the membrane surfaces, $2 r_{\mathrm{f}}$, the membrane porosity by the apparent density method
$\operatorname{Pr}\left(\mathrm{d}_{3}\right)$ and the membrane thickness $L_{\mathrm{d}}$ and to determine the most important factors among casting conditions governing the membrane structure.

\section{EXPERIMENTAL}

\section{Molecular Weight of Cellulose Sample}

Cotton cellulose purified by conventional alkali digestion method was dissolved in cadoxen (cadmium oxide/ ethylene diamine/sodium hydroxide/water $=5 / 28 / 1.4 / 116$ in weight ratio) to prepare several cellulose solutions with different concentration of cellulose below $0.4 \mathrm{~g} \mathrm{dl}^{-1}$. Viscosity of the cellulose solution was measured at $25^{\circ} \mathrm{C}$ and the viscosity-average molecular weight $M_{v}$ was estimated using eq $1^{13}$ :

$$
[\eta]=3.85 \times 10^{-2} M_{v}^{0.76},
$$

where $[\eta]$ is limiting viscosity number $\left[\mathrm{ml} \mathrm{g}^{-1}\right]$ of the solution. $M_{v}$ of the cotton cellulose was $1.94 \times 10^{5}$.

\section{Membrane Preparation}

The purified cotton cellulose was dissolved at $10^{\circ} \mathrm{C}$ in cuprammonium solution to give an original cellulose solution (weight fraction of cellulose $w_{\text {Cell }}=0.10$; weight fraction of ammonia $w_{\mathrm{NH}_{3}}=0.068$; weight fraction of copper $w_{\mathrm{Cu}}=0.031$; weight fraction of water $w_{\mathrm{H}_{2} \mathrm{O}}=0.801$ ) for preparation of porous polymeric membranes.

By diluting the solution with aqueous ammonia solution $\left(w_{\mathrm{NH}_{3}}=0.28\right.$; Kishida Chemicals Co., Ltd., Osaka, Japan), three cellulose solutions with different $w_{\text {Cell }}=$ $0.05-0.07$ and different $w_{\mathrm{NH}_{3}}$ (hereafter, referred to as series I for preparation of cuprammonium cellulose solutions) were prepared and their compositions are listed in Table I (code \#I-4, 5, and 6).

In the same manner as described above, another cellulose solution with $w_{\mathrm{Cell}}=0.10, w_{\mathrm{NH}_{3}}=0.08, w_{\mathrm{Cu}}=$ 0.036 , and $w_{\mathrm{H}_{2} \mathrm{O}}=0.784$ was prepared and used as alternative original solution. By diluting the solution with aqueous ammonium solution with $w_{\mathrm{NH}_{3}}=0.08$, five cellulose solutions with $w_{\text {Cell }}=0.04-0.08$ and constant $w_{\mathrm{NH}_{3}}=0.08$ (hereafter referred to as series II) were prepared and detailed compositions of each solution are also compiled in Table I (code \# II-1 and II-3 to II-7).

Two additional series of cellulose solutions with constant $w_{\text {Cell }}$ and constant $w_{\mathrm{Cu}}$ (series III, $w_{\mathrm{Cell}}=0.06$; 
Table I. Compositions of casting cellulose cuprammonium solutions and coagulation solutions

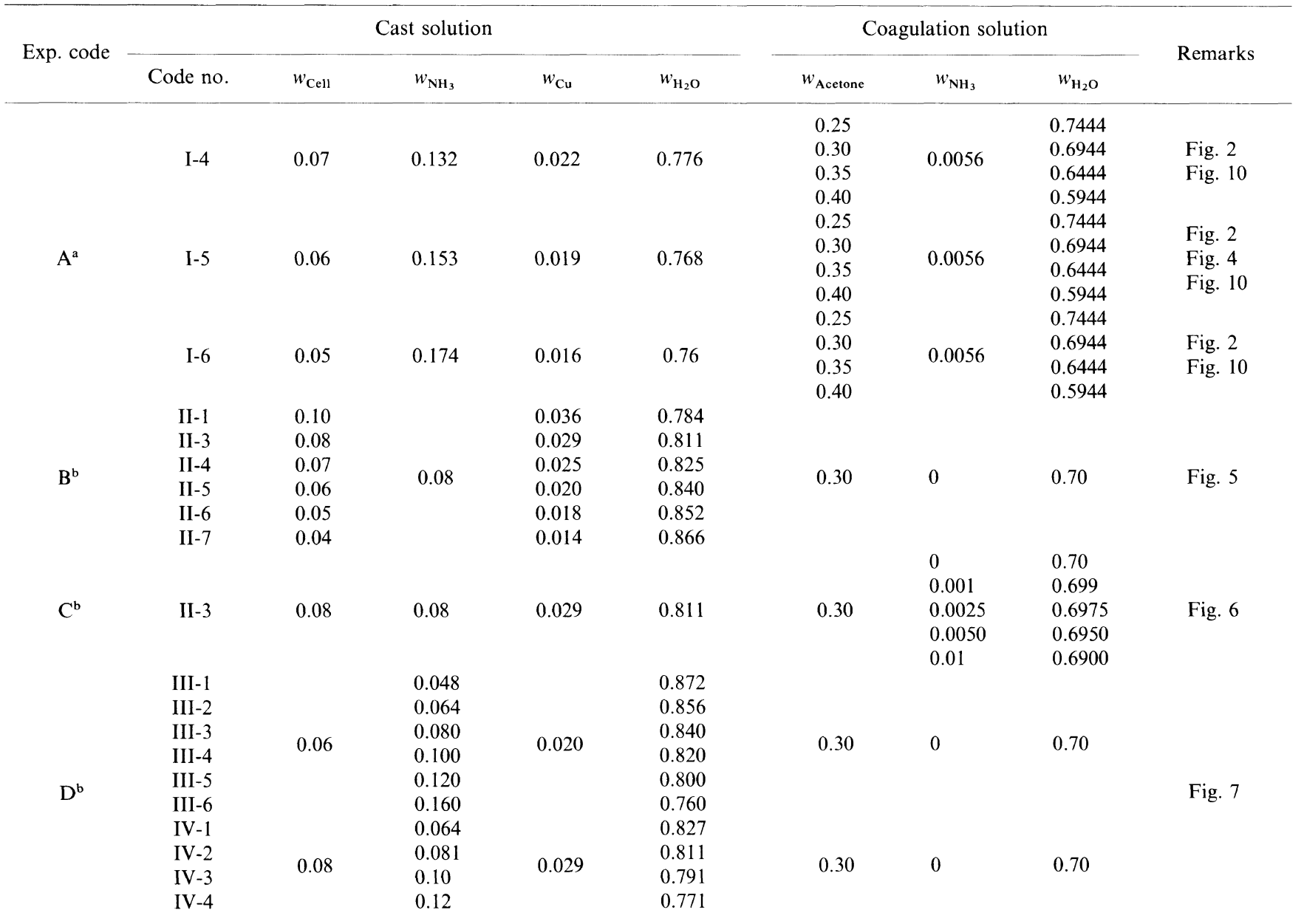

${ }^{\mathrm{a}}$ Thickness of cast solution $L_{0}=500 \mu \mathrm{m} .{ }^{\mathrm{b}} L_{0}=250 \mu \mathrm{m}$.

$w_{\mathrm{Cu}}=0.020 ;$ series IV, $\left.w_{\mathrm{Cel1}}=0.08 ; w_{\mathrm{Cu}}=0.029\right)$ were prepared directly from cotton cellulose and aqueous cuprammonium solution to give final compositions which are also listed in Table I (code \# III-1 to III-6 and IV-1 to IV-4).

Cellulose membranes were produced, where any notice was not made, in the following manner: Cuprammonium cellulose solution was cast on a flat glass plate with thickness $L_{0}$ of $250 \mu \mathrm{m}$ or $500 \mu \mathrm{m}$, and the cast solution on the plate was immersed into coagulation solution consisting of acetone, ammonia, and water for $30 \mathrm{~min}$ at $25^{\circ} \mathrm{C}$ without any further agitation. The resultant gel membranes i.e., coagulated cellulose solutions, were dipped in $2 \mathrm{wt} \%$ aqueous sulfuric acid at $20^{\circ} \mathrm{C}$ for 30 min in order to regenerate cellulose (step $\mathrm{j}$ in Figure 1). Regenerated cellulose membranes were washed with water at $20^{\circ} \mathrm{C}$ for $6 \mathrm{~h}$, and then immersed in pure acetone at $20^{\circ} \mathrm{C}$ for more than $6 \mathrm{~h}$ for replacing water with acetone completely. These membranes were air-dried at room temperature for more than $24 \mathrm{~h}$ at constant length.

In order to examine effects on membrane characteristics of (1) $w_{\text {Acetone }}$ in coagulation solution, (2) $w_{\text {Cell }}$, (3) $w_{\mathrm{NH}_{3}}$ in coagulation solution, and (4) $w_{\mathrm{NH}_{3}}$ in cast solution, four series of experiments (A to D) for membrane preparation were carried out: Table I also collects detailed experimental conditions employed here: (A) cast cellulose solutions in series I were coagulated in aqueous acetone solutions having various $w_{\text {Acetone }}$ and constant $w_{\mathrm{NH}_{3}} ;$ (B) membranes were prepared by casting cellulose solutions having different $w_{\text {Cell }}$ and constant $w_{\mathrm{NH}_{3}}$ (series II) and then by immersing into the same aqueous acetone solution; (C) cast cellulose solution (series II-3) was coagulated in aqueous acetone solutions with constant $w_{\text {Acetone }}(=0.30)$ in a range of $w_{\mathrm{NH}_{3}}$ from 0 to 0.01 ; (D) cellulose solutions of series III were cast and then were coagulated by immersing them into aqueous acetone solution $\left(w_{\text {Acetone }}=0.30, w_{\mathrm{H}_{2} \mathrm{O}}=0.70\right.$, $w_{\mathrm{NH}_{3}}=0$ ).

For the determination of density at $25^{\circ} \mathrm{C}\left(\equiv d^{25}\right)$ of solutions I-4, I-5, and I-6, volume of the solution settled at $25^{\circ} \mathrm{C}$ in a measuring cylinder was measured after air bubbles were completely eliminated from the solutions under vacuum. Weight of the solution was estimated by subtracting weight of the measuring cylinder itself from a total weight of both the cylinder and the solution in it.

\section{Measurements of Membrane Characteristics}

Porosity of Membrane. Porosity of membrane $\mathrm{Pr}$ was evaluated from apparent density $d_{\mathrm{A}}$ of a membrane and density of a materials constructing the membrane $d_{\mathrm{PL}}$ through use of eq 2 . The porosity determined by this method (referred to as apparent density method) was denoted as $\operatorname{Pr}\left(\mathrm{d}_{3}\right)^{5}$;

$$
\operatorname{Pr}\left(\mathrm{d}_{3}\right)=1-\left(d_{\mathrm{A}} / d_{\mathrm{PL}}\right),
$$

where $d_{\mathrm{A}}=w_{\mathrm{m}} / v_{\mathrm{m}}\left(w_{\mathrm{m}}, v_{\mathrm{m}}\right.$ are weight and volume of the 
absolute dry membrane, respectively). Density of crystalline cellulose $\left(=1.531 \mathrm{~g} \mathrm{~cm}^{-3}\right)^{14}$ was taken as $d_{\mathrm{PL}}$.

Mean Pore Radius by Water-Flow-Rate Method. Mean pore radius was evaluated by the water-flow rate method $r_{\mathrm{f}}[m]$ by putting porosity $\operatorname{Pr}\left(\mathrm{d}_{3}\right)[-]$, filtration rate per unit area of membrane $J\left[\mathrm{~m}^{3} \mathrm{~m}^{-2} \mathrm{~s}{ }^{-1}\right]$, and thickness of dry membrane $L_{\mathrm{d}}[\mathrm{m}]$, all experimentally determined, into eq 3, which was derived on the basis of the straight-through cylindrical pore $\operatorname{model}^{15}$;

$$
r_{\mathrm{f}}=\sqrt{\frac{8 \eta_{\mathrm{H}_{2} \mathrm{O}} J L_{\mathrm{d}}}{\operatorname{Pr}\left(\mathrm{d}_{3}\right) \Delta P}},
$$

where $\eta_{\mathrm{H}_{2} \mathrm{O}}\left[\mathrm{N} \mathrm{sm}^{-2}\right]$ is viscosity of water, and $\Delta P$ $\left[\mathrm{N} \mathrm{m}^{-2}\right]$, loaded pressure.

Electron Microscopic Observation. Electron micrographs of surfaces and cross sections of the membranes were taken using a field emission electron scanning microscope (FE-SEM S-800, manufactured by Hitachi, Ltd., Tokyo, Japan). For observation of cross sections of membranes, membranes were broken into pieces in liquid nitrogen.

Tensile Strength TS of Membrane. Test specimens, which were $15 \mathrm{~mm}$ in width by $20 \mathrm{~mm}$ in length, were cut out from dry membranes, and were kept in an atmosphere having $65 \%$ relative humidity at $20^{\circ} \mathrm{C}$. By using Tensilon model UTM-III-100 (Toyo Baldwin Co., Ltd., Tokyo, Japan), tensile strength was measured at a rate of $20 \mathrm{~mm} \mathrm{~min}^{-1}$ in the same atmosphere $(65 \%$ relative humidity at $20^{\circ} \mathrm{C}$ ) and tensile strength per unit area of a cross-section of dry membrane $T S$ was evaluated.

\section{RESULTS AND DISCUSSION}

\section{Liquid-Liquid Two-Phase Separation in a System of Cuprammonium Cellulose Solution/Acetone/Water}

Pure acetone was added drop by drop using an injection cylinder attached with a needle to cuprammonium cellulose solution $\left(w_{\text {Cell }}=0.10 ; w_{\mathrm{Cu}}=0.036 ; w_{\mathrm{NH}_{3}}=0.144\right.$; $\left.w_{\mathrm{H}_{2} \mathrm{O}}=0.72\right)$ in a glass bottle, and they were mixed completely. After a given amount of acetone was added, the bottle was sealed tightly with a screw cap. A whole composition of the phase-separated solution was as follows: $w_{\text {Cell }}=0.044 ; w_{\mathrm{Cu}}=0.017 ; w_{\mathrm{NH}_{3}}=0.069 ; w_{\text {Acetone }}=0.202$; $w_{\mathrm{H}_{2} \mathrm{O}}=0.668$. Settled in an incubation bath at $25^{\circ} \mathrm{C}$ for more than $8 \mathrm{~h}$, the solution was separated into two liquid phases; polymer-rich and polymer-lean phases.

\section{Effect of Acetone Concentration of Coagulation Solution on Pore Structure}

Figure 2 shows scanning electron micrographs of the surfaces of membranes, which were prepared under conditions of the experiment $\mathrm{A}$.

At least in the range of $0.05<w_{\text {Cell }}<0.07$, surface of all membranes, prepared by immersing the cast solutions in the coagulation solutions with $w_{\text {Acetone }}<0.30$, was evidently composed of cellulose secondary particles (Figures 2a, 2b, 2e, 2f, 2i, and 2j). Membrane structure changes abruptly from noncircular pores to circular pores when $w_{\text {Acetone }}$ in the coagulation solutions exceeds 0.30 (Figures $2 \mathrm{c}, 2 \mathrm{~d}, 2 \mathrm{~g}, 2 \mathrm{~h}, 2 \mathrm{k}$, and 21). $w_{\text {Acetone }}$ governs phase separation characteristics such as two phase volume ratio
$R\left(\equiv V_{(1)} / V_{(2)} ; V_{(1)}\right.$ and $V_{(2)}$ are volumes of polymerlean and -rich phases, respectively), and compositions of phase separation points.

Densities at $25^{\circ} \mathrm{C}\left(d^{25}\right)$ of cast solutions (code I-4, I-5, and I-6) were $1.02\left[\mathrm{~g} \mathrm{~cm}^{-3}\right], 0.993$, and 0.968 , respectively. From these data, molar concentrations of ammonia $m_{\mathrm{NH}_{3}}$ and of water $m_{\mathrm{H}_{2} \mathrm{O}}$ in the solutions were calculated; $7.92\left[\mathrm{moll}^{-1}\right]$ and $44.0\left[\mathrm{moll}^{-1}\right]$ for I-4, 8.94 and 42.4 for I-5, and 9.91 and 40.9 for I-6. Using literature data for density of aqueous acetone solution, ${ }^{16} w_{\text {Acetone }}$ of coagulation solutions having the same $m_{\mathrm{H}_{2} \mathrm{O}}$ as that of the cast solution (referred to as critical $w_{\text {Acetone }}$ ) can be evaluated; in cases of I-4 $\left(w_{\mathrm{Cell}}=0.07 ; m_{\mathrm{H}_{2} \mathrm{O}}=44.0\right), \mathrm{I}-5$ $\left(w_{\mathrm{Cell}}=0.06 ; m_{\mathrm{H}_{2} \mathrm{O}}=42.4\right)$, and I-6 $\left(w_{\mathrm{Cell}}=0.05 ; m_{\mathrm{H}_{2} \mathrm{O}}=\right.$ 40.9 ), the critical $w_{\text {Acetone }}$ were $0.186,0.212$, and 0.236 , respectively.

Figure 3 represents a semi-quantitative phase diagram for cellulose/cuprammonium solution/acetone system. Note that this system is not a simple system of polymer/ solvent/nonsolvent, and that it is impossible to draw a two-dimensional phase diagram for this system. Accordingly, this figure is not a quantitative phase diagram obtained by phase separation experiments, but a general, qualitative one modeled after a phase diagram for a system of polymer/solvent/nonsolvent. In the figure, a thick full curve and a thin full curve represent cloud point curve (CPC) and gelation line, respectively. An open circle and a closed circle represent composition of critical solution point (volume fraction of polymer is $v_{\mathrm{p}}^{\mathrm{c}}$ ) and that of starting solution (i.e., cast cellulose solution; volume fraction of polymer is $v_{\mathrm{p}}^{\mathrm{s}}$ ), respectively.

In practice, $m_{\mathrm{H}_{2} \mathrm{O}}$ values of the cast solutions are nearly equal to those of coagulation solutions with $w_{\text {Acetone }}$ ranging from 0.20 to 0.25 . Therefore, water molecules scarcely move across an interface between the cast cellulose solution and the coagulation solutions. Composition of the cast solution changes along curve SAN; it comes across the CPC at point $\mathrm{A}$, where initial polymer volume fraction $v_{\mathrm{p}}^{0}$ is less than $v_{\mathrm{p}}^{\mathrm{c}}$.

The magnitude of mole flux of non-electrolyte component i, $f_{\mathrm{i}}\left[\mathrm{mol} \mathrm{cm} \mathrm{c}^{-2} \mathrm{~s}^{-1}\right]$ can be estimated by

$$
f_{\mathrm{i}}=-D_{\mathrm{i}} \frac{\partial C_{\mathrm{i}}}{\partial Z}
$$

where $D_{\mathrm{i}}$ is the diffusion coefficient of the component $\mathrm{i}$ $\left[\mathrm{cm}^{2} \mathrm{~s}^{-1}\right], \partial C_{\mathrm{i}} / \partial Z\left[\mathrm{~mol} \mathrm{~cm}{ }^{-4}\right]$, the concentration gradient of the component $i$ at the interface between cast solution and coagulation solution. $D_{\mathrm{i}}\left[\mathrm{cm}^{2} \mathrm{~s}^{-1}\right]$ was found to be $1.77 \times 10^{-9}(288 \mathrm{~K})$ for ammonia (in water), $1.16 \times 10^{-9}(293 \mathrm{~K})$ for acetone (in water) and $2.27 \times$ $10^{-9}(293 \mathrm{~K})$ for water. ${ }^{17}$ Here the relative mole flux $f_{\mathrm{i}}{ }^{*}$ is defined as ratio of mole flux $f_{\mathrm{i}}$ of each component to that of $\mathrm{H}_{2} \mathrm{O}$ in case where $w_{\text {Cell }}$ of cast solution $=0.05$ and $w_{\text {Acetone }}$ of coagulation solution $=0.25$. Molar concentration of acetone $m_{\text {Acetone }}$ and that of water $m_{\mathrm{H}_{2} \mathrm{O}}$ in coagulation solution were calculated by using literature data of $d^{25}$ of aqueous acetone solutions: $m_{\text {Acetone }}$ [moll $\left.{ }^{-1}\right]$ and $m_{\mathrm{H}_{2} \mathrm{O}}\left[\mathrm{moll}^{-1}\right]$ were 4.15 and 40.1 for aqueous acetone solution with $w_{\text {Acetone }}=0.25 ; 4.91$ and 37.1 for $w_{\text {Acetone }}=0.35 ; 7.90$ and 25.5 for $w_{\text {Acetone }}=0.50$, respectively. $f_{\mathrm{i}}^{*}$ values, calculated by using molar concentration of cast solution and coagulation solution, are summarized in Table II. 
a)

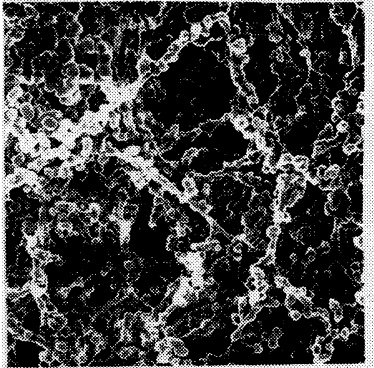

e)

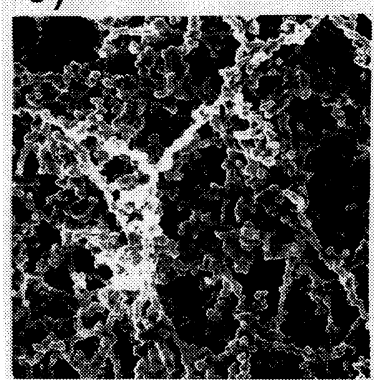

i)

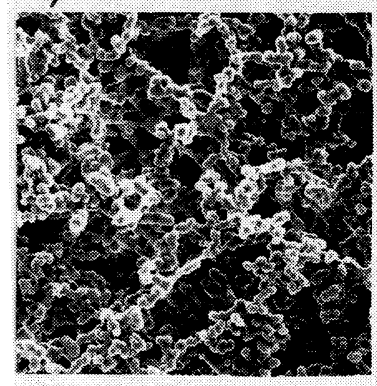

b)

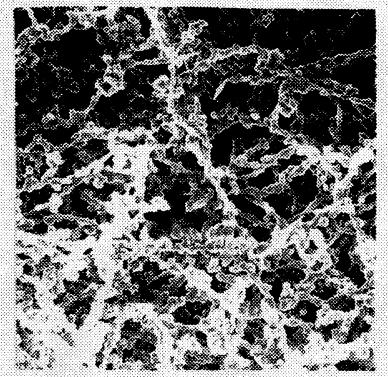

f)

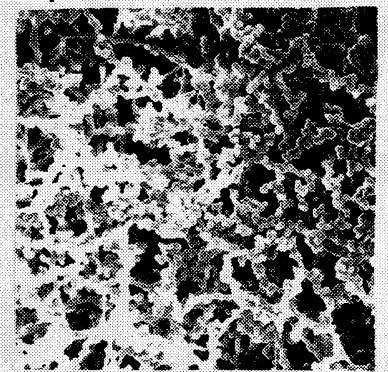

j)

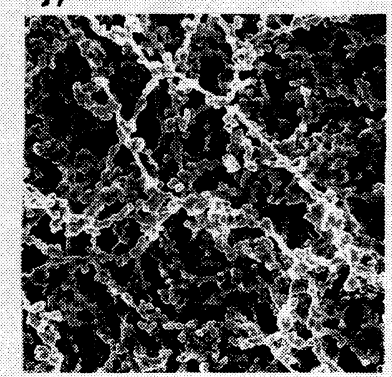

c)

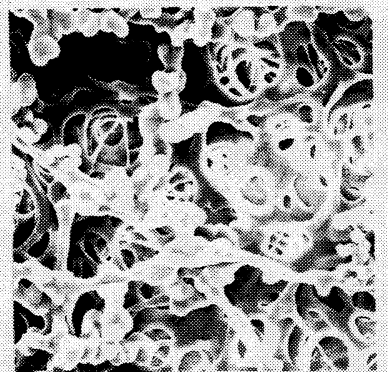

g)

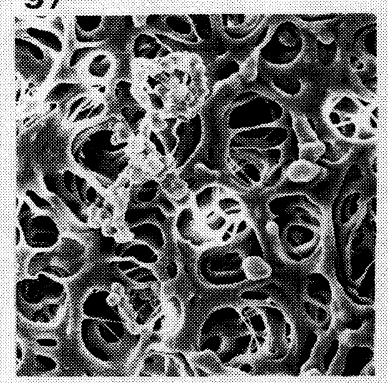

k)

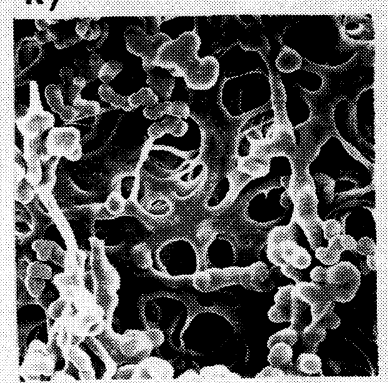

d)

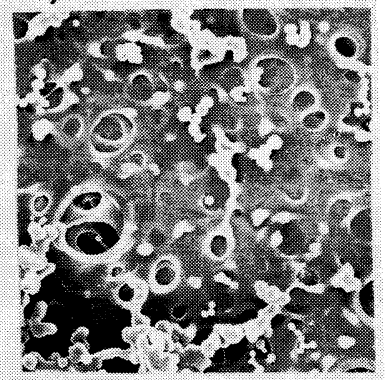

h)

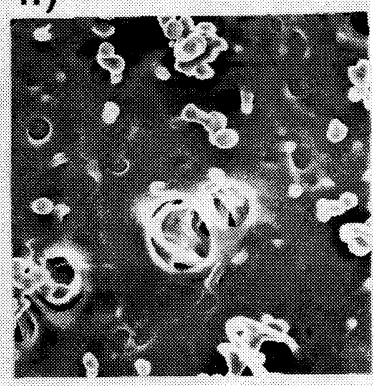

1)

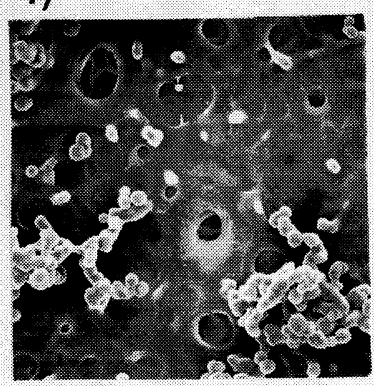

$10 \mu \mathrm{m}$

Figure 2. Scanning electron micrographs of surfaces of the cellulose membranes regenerated from cellulose cuprammonium solution by the phase separation method: Effect of the weight fraction of acetone $w_{\text {Acetone }}$ in coagulation solutions on pore shape of surfaces of the membranes; cast solutions were prepared using series I (see, Table I); thickness of cast solution $L_{0}, 500 \mu \mathrm{m}$; weight fraction of cellulose $w_{\text {Cell }}$ in cast solutions, a) - d), $0.05 ;$ e) - h), 0.06 ; i) - - l), 0.07; compositions of the coagulation solutions, weight fraction of acetone $w_{\text {Acetone }} /$ weight fraction of ammonia $w_{\mathrm{NH}_{3}}$ (weight fraction of water $\left.w_{\mathrm{H}_{2} \mathrm{O}}, \mathrm{a}\right)$, e), and i), 0.25/0.0056/0.7444; b), f), and j), 0.30/0.0056/0.6944; c), g) and k), 0.35/0.0056/0.6444; d), h) and 1$), 0.50 / 0.0056 / 0.4944$.

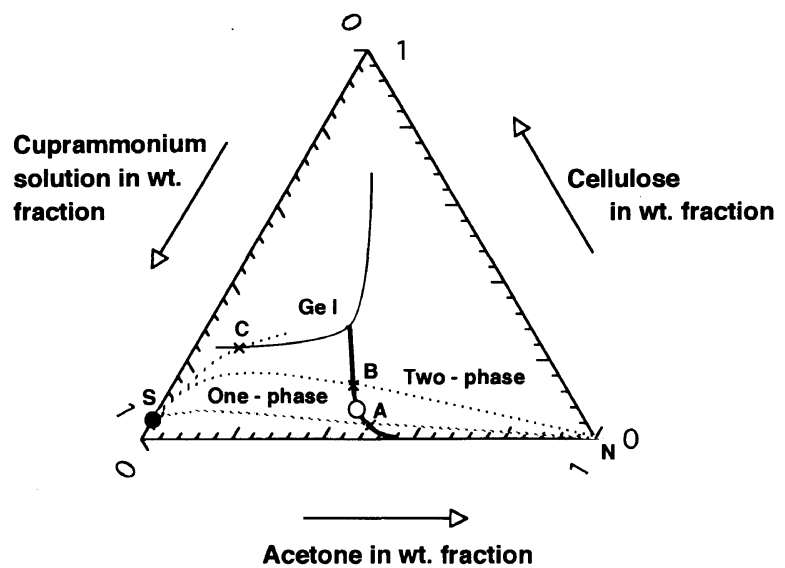

Figure 3. Qualitative phase diagram for a system of cellulose/cuprammonium solution/acetone: Thick full curve, cloud point curve (CPC); thin full curve, gelation line; open circle, critical solution point; closed circle, starting solution (i.e., cast cellulose solution).
Table II. Relative magnitude of mole flux of water, ammonia and acetone across an interface between cast solution and coagulation solution

\begin{tabular}{|c|c|c|c|c|c|c|}
\hline \multicolumn{2}{|c|}{ Cast solution } & \multicolumn{2}{|c|}{$\begin{array}{l}\text { Coagulation } \\
\text { solution }\end{array}$} & \multicolumn{3}{|c|}{$f_{\mathrm{i}}^{* \mathrm{a}}$} \\
\hline Code & $w_{\text {Cell }}$ & $w_{\text {Acetone }}$ & $w_{\mathrm{H}_{2} \mathrm{O}}$ & $\mathrm{H}_{2} \mathrm{O}$ & $\mathrm{NH}_{3}$ & Acetone \\
\hline \multirow{4}{*}{ I-6 } & \multirow{4}{*}{0.05} & 0.25 & 0.75 & 1.00 & 9.62 & -2.64 \\
\hline & & 0.30 & 0.70 & 4.74 & 9.62 & -3.15 \\
\hline & & 0.35 & 0.65 & 8.46 & 9.62 & -3.64 \\
\hline & & 0.50 & 0.50 & 19.2 & 9.62 & -5.03 \\
\hline \multirow{4}{*}{$\mathrm{I}-5$} & \multirow{4}{*}{0.06} & 0.25 & 0.75 & 2.87 & 8.35 & -2.64 \\
\hline & & 0.30 & 0.70 & 6.59 & 8.35 & -3.15 \\
\hline & & 0.35 & 0.65 & 10.3 & 8.35 & -3.64 \\
\hline & & 0.50 & 0.50 & 21.1 & 8.35 & -5.03 \\
\hline \multirow{4}{*}{ I-4 } & \multirow{4}{*}{0.07} & 0.25 & 0.75 & 4.86 & 7.70 & -2.64 \\
\hline & & 0.30 & 0.70 & 8.63 & 7.70 & -3.15 \\
\hline & & 0.35 & 0.65 & 12.3 & 7.70 & -3.64 \\
\hline & & 0.50 & 0.50 & 23.1 & 7.70 & -5.03 \\
\hline
\end{tabular}

${ }^{a}$ Ratio of mole flux $f_{\mathrm{i}}$ of each component to that of $\mathrm{H}_{2} \mathrm{O}$ in case where $w_{\text {Cell }}$ of cast solution $=0.05$ and $w_{\text {Acetone }}$ of coagulation solution $=$ 0.25 . 
In case of $w_{\text {Acetone }}$ of coagulation solution $>0.25$, water molecules move from cellulose solution to coagulation solution, and acetone molecules penetrate into the cellulose solution immediately after an interface between the cast solution and the coagulation solution is formed, resulting in an increase of $w_{\text {Cell }}$ of the cast solution, because the total flux (in mole) of water and ammonia from the cast solution $\left(f^{*}=\sum f_{\mathrm{i}}^{*}\right)$ to the coagulation solution is larger than that of acetone from the coagulation solution to the cast solution (Table II).

In case of the critical $w_{\text {Acetone }}<w_{\text {Acetone }}$ of coagulation

a)

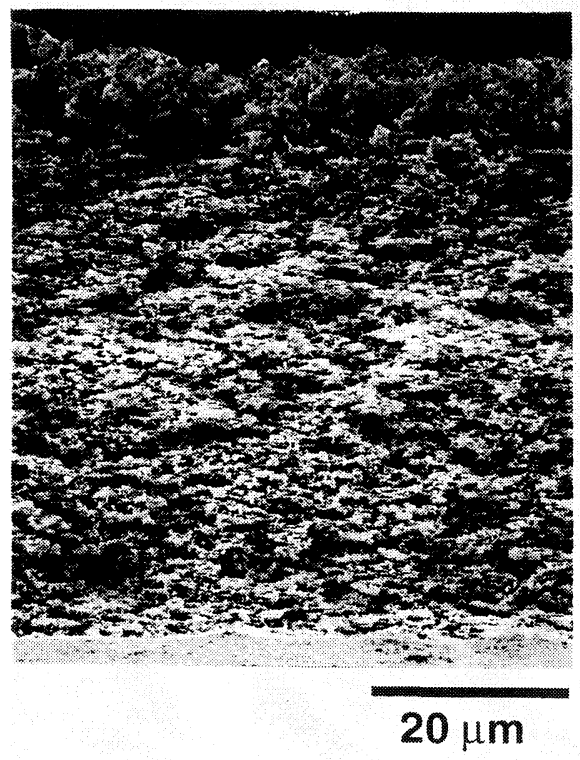

b)

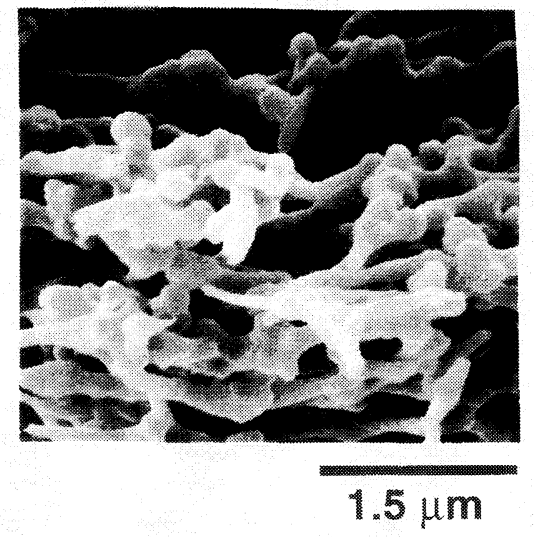

c)

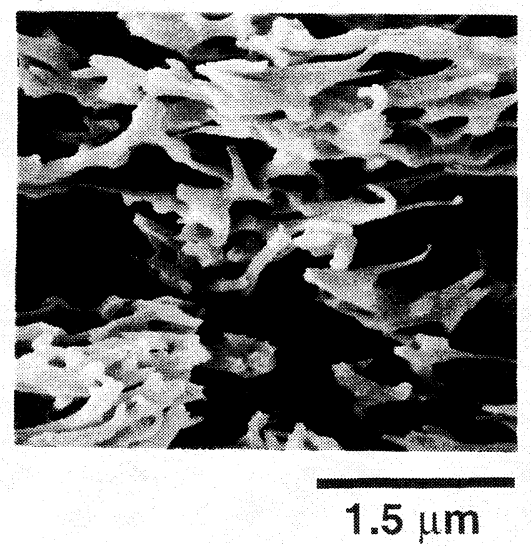

solution $<0.30, m_{\mathrm{H}_{2} \mathrm{O}}$ values in both sides of the interface is practically equal; moving rate of water across the interface is extremely small, whereas that of ammonia is the largest among the three components. Therefore, $w_{\text {Cell }}$ of the cast solution increases gradually, and then decreases, approaching to point $\mathrm{N}$ along curve SAN in Figure 3. The composition of the cast solution crosses the CPC at point $\mathrm{A}$, where $v_{\mathrm{p}}^{0}$ is smaller than $v_{\mathrm{p}}^{\mathrm{c}}$.

In cases of $0.30<w_{\text {Acetone }}$ of coagulation solution $<0.50$, mole flux of water from cast solution to coagulation solution is the largest, and the composition of the

\section{d)}

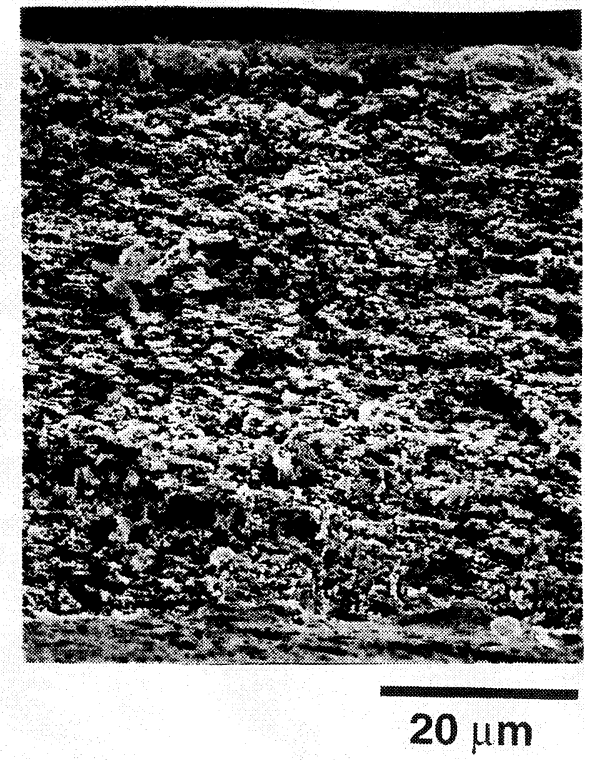

e)

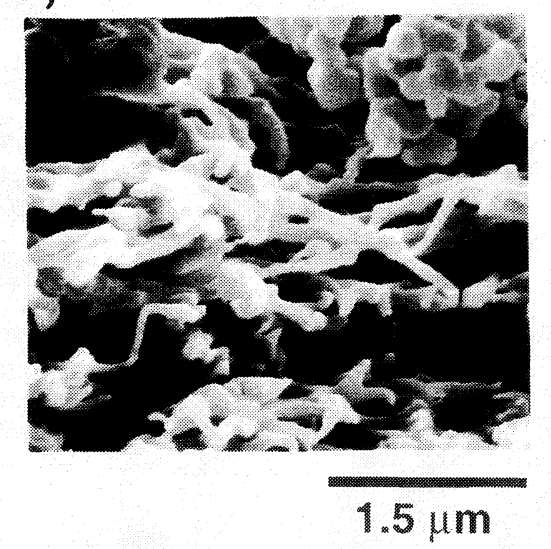

f)

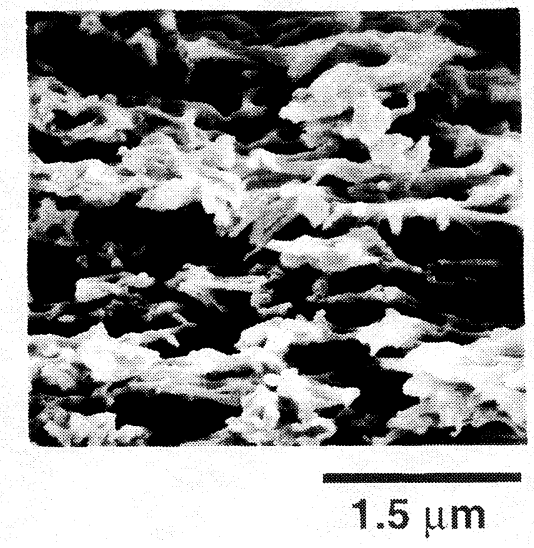


cast solution changes along curve $\mathrm{SBN} ; w_{\text {Cell }}$ of the cast solution increases at first, passing a maximum, and then decreases, approaching to point $\mathrm{N}$. Polymer concentration of the cast solution at point $\mathrm{B}$, i.e., $v_{\mathrm{p}}^{0}$ is larger than $v_{\mathrm{p}}^{\mathrm{c}}$.

When the cellulose solutions cast on glass plates were

g)

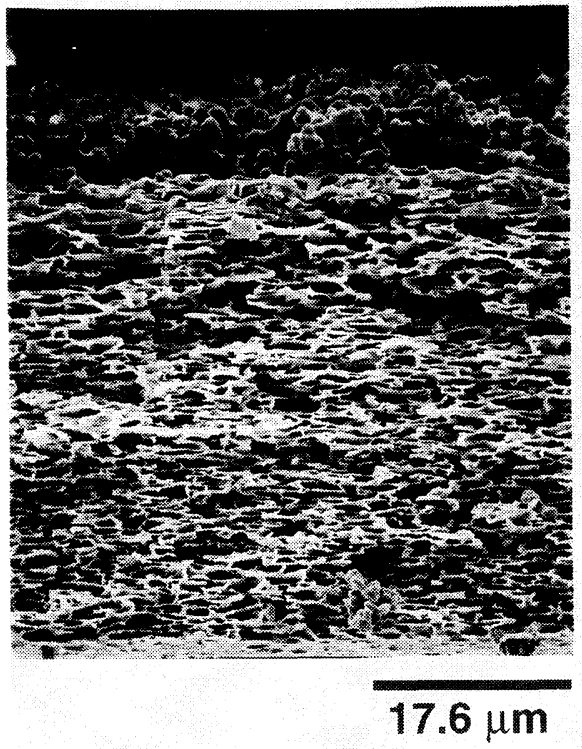

h)

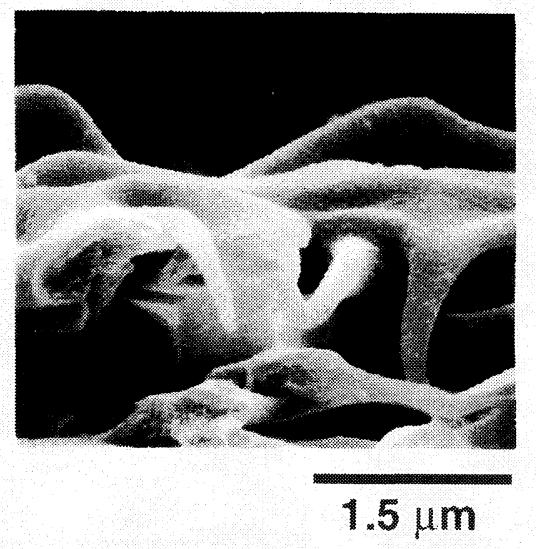

i)

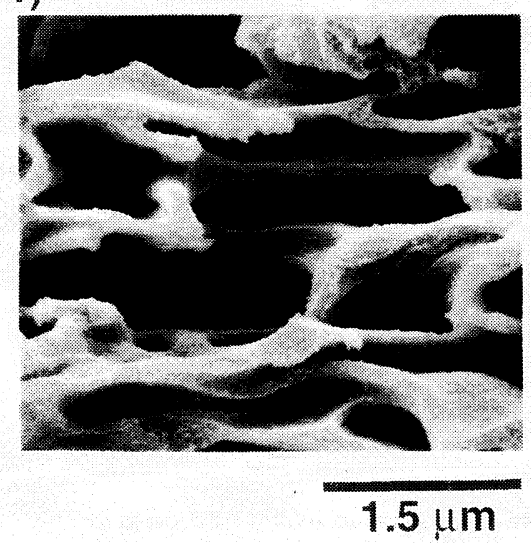

immersed in aqueous acetone solution of $w_{\text {Acetone }}=0.70$, rapid gelation occurred and neither polymer particles nor circular pores observed on the top surface of the membranes. In this case, composition of the cellulose solution changes along curve SC, going into a gel region.

Figure 4 shows electron micrographs of cross sections

j)

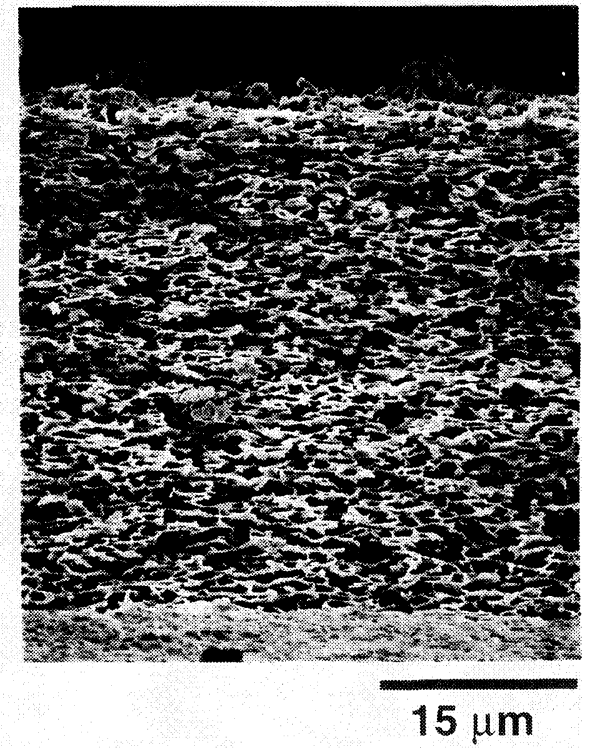

k)

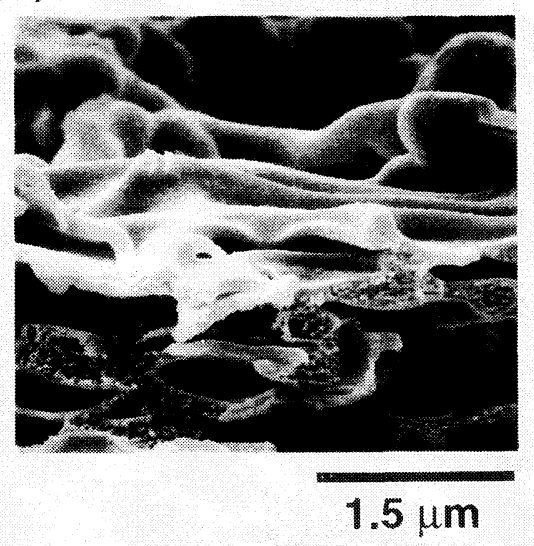

I)

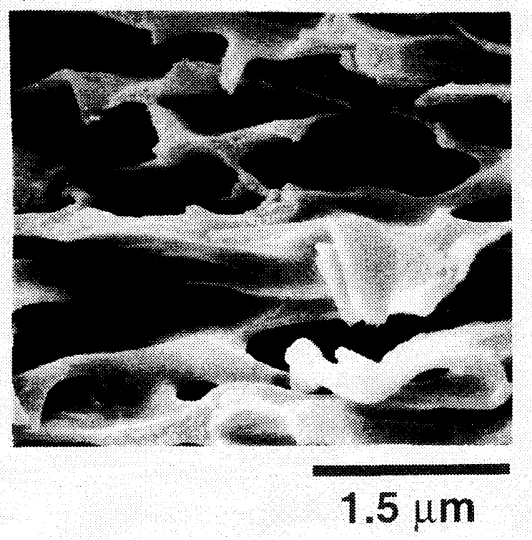

Figure 4. Scanning electron micrographs of cross-section of the cellulose membranes regenerated from cellulose cuprammonium solution by the phase separation method: Effect of weight fraction of acetone $w_{\text {Acetone }}$ of the coagulation solutions on membrane structure; cast solutions were prepared using series I (see, Table I); weight fraction of cellulose $w_{\text {Cell }}$ of the cast solutions, 0.06 ; compositions of the coagulation solutions, weight fraction of acetone $w_{\text {Acetone }}$ /weight fraction of ammonia $w_{\mathrm{NH}_{3}}$ /weight fraction of water $w_{\mathrm{H}_{2} \mathrm{O}}$, a) $-\mathrm{c}$ ), $\left.0.25 / 0.0056 / 0.7444 ; \mathrm{d}\right)-\mathrm{f}$ ), 0.30/0.0056/0.6944; g) -i), $0.35 / 0.0056 / 0.6444 ; \mathrm{j}$ ) - l), 0.40/0.0056/0.5944; thickness of the cast solution $\left.\left.L_{0}, 500 \mu \mathrm{m} ; \mathrm{a}\right), \mathrm{d}\right), \mathrm{g}$ ), and j), cross-section from front surface to back surface; b), e), h), and k), cross-section of the front surface; c), f), i), and 1), cross-section of a inner part of the membrane. 
of the membranes prepared by immersing the cast solution $\left(w_{\text {Cell }}=0.06\right.$; I-5 in Table I) in the coagulation solutions $\left(w_{\text {Acetone }}=0.25-0.40 ; w_{\mathrm{NH}_{3}}=0.0056\right)$. Preparation conditions are summarized in the column of code I-5 in Experiment $\mathrm{A}$ in Table I. In cases of $w_{\text {Acetone }}=0.25$ and 0.30 (Figures $4 \mathrm{a}-\mathrm{f}$ ), whole body of membranes was composed of numerous cellulose secondary particles forming network-like structure. In contrast to this, in cases of $w_{\text {Acetone }}=0.35$ and 0.40 (Figures $4 \mathrm{~g}-1$ ), membranes were not composed of polymer particles, but they were composed of piled flat sheets having many cells, in which polymer-lean phase was filled during coagulation. As these cells were observed as circular pores in Figures $2 \mathrm{~g}$ and $2 \mathrm{~h}$, they were referred to as pore particles. Depending on an increase in $w_{\text {Acetone }}$ of coagulation solution, pore shape of the membranes prepared from the cellulose solutions of $w_{\mathrm{Cell}}=0.05$ and 0.07 (I-4 and I-6 in Table I) changed from non-circular pore to circular pore in a range of $w_{\text {Acetone }}$ from 0.30 to 0.35 (electron micrographs are not shown here).

From Figures 2 and 4, it was confirmed for cellulose/ cuprammonium solution/aqueous acetone system that membrane having either all noncircular pores or all

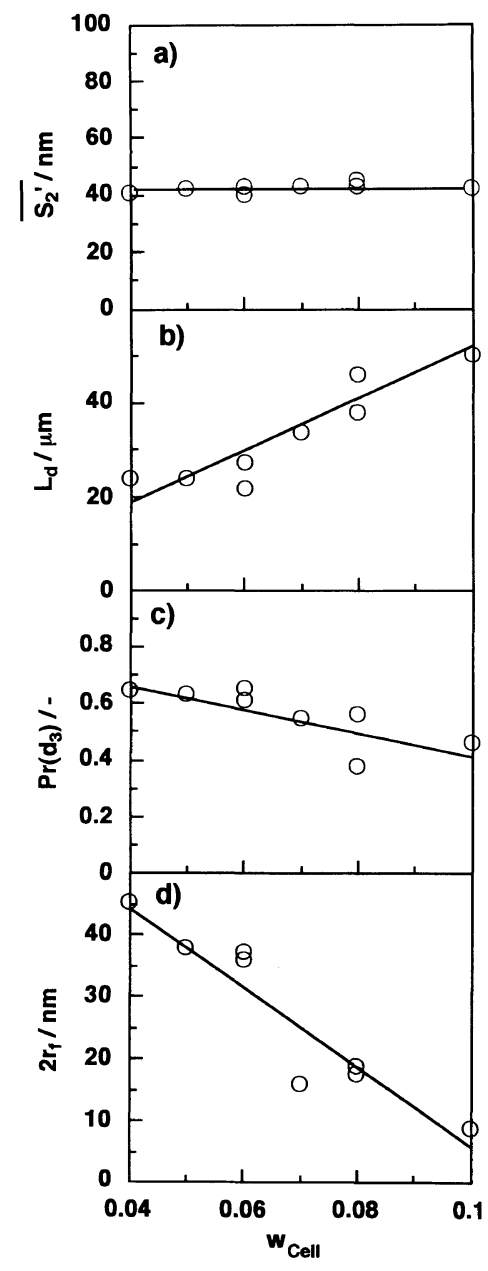

Figure 5. Effects of weight fraction of cellulose $w_{\text {Cel1 }}$ of the cast solution on mean radius of dry polymer particles $\overline{S_{2}^{\prime}}(\mathrm{a})$, thickness of the dry membrane $L_{\mathrm{d}}(\mathrm{b})$, porosity of the membranes $\operatorname{Pr}\left(\mathrm{d}_{3}\right)(\mathrm{c})$, and mean diameter of pores measured by the water-flow-rate method $2 r_{\mathrm{f}}(\mathrm{d})$ : Compositions of the cast solution, weight fraction of ammonia $w_{\mathrm{NH}_{3}}$, 0.08 ; weight fraction of cellulose $w_{\text {Cell }}, 0.04-0.10$; compositions of the coagulation solution, weight fraction of acetone $w_{\text {Acetone }}, 0.30$; weight fraction of ammonia $w_{\mathrm{NH}_{3}}, 0.08$; thickness of cast solutions $L_{0}, 250 \mu \mathrm{m}$. circular pores can be obtained by choosing adequate casting conditions.

\section{Effect of Cellulose Concentration}

Cellulose solutions (series II) were cast to give a layer with $250 \mu \mathrm{m}$ thickness, which were immersed in coagulation solution $\left(w_{\text {Acetone }}=0.30, w_{\mathrm{NH}_{3}}=0.08\right)$. Mean radii of secondary particles observed on their surfaces are almost the same, irrespective of cellulose concentration (Figure 5a). This fact suggests strongly that cellulose concentration does not govern significantly the size of cellulose particles. Thickness of dry membranes $L_{\mathrm{d}}$ is in proportion to $w_{\text {Cell }}$ (Figure $5 \mathrm{~b}$ ), but $\operatorname{Pr}\left(\mathrm{d}_{3}\right)$ and $2 r_{\mathrm{f}}$ are inversely proportional to $w_{\text {Cell }}$ (Figures $5 \mathrm{c}$ and $5 \mathrm{~d}$ ).

These facts indicate that density of dry polymer particles $d_{\mathrm{P}}^{\prime}$ becomes higher with an increase in $w_{\text {Cell }}$ of cast solution. Results of the previous paper ${ }^{5}$ gave the same relation between $w_{\text {Cell }}$ and $d_{\mathrm{P}}^{\prime}$ (see, Table IV of ref 5).

Effects of Ammonia Concentration of Coagulation Solution and Cast Solution on Radius of Secondary Particles, Porosity, Thickness, and Pore Size of Dry Membrane

Figure 6a shows relation between $w_{\mathrm{NH}_{3}}$ of coagulation solution and mean radius of dry polymer particles $\overline{S_{2}^{\prime}}$

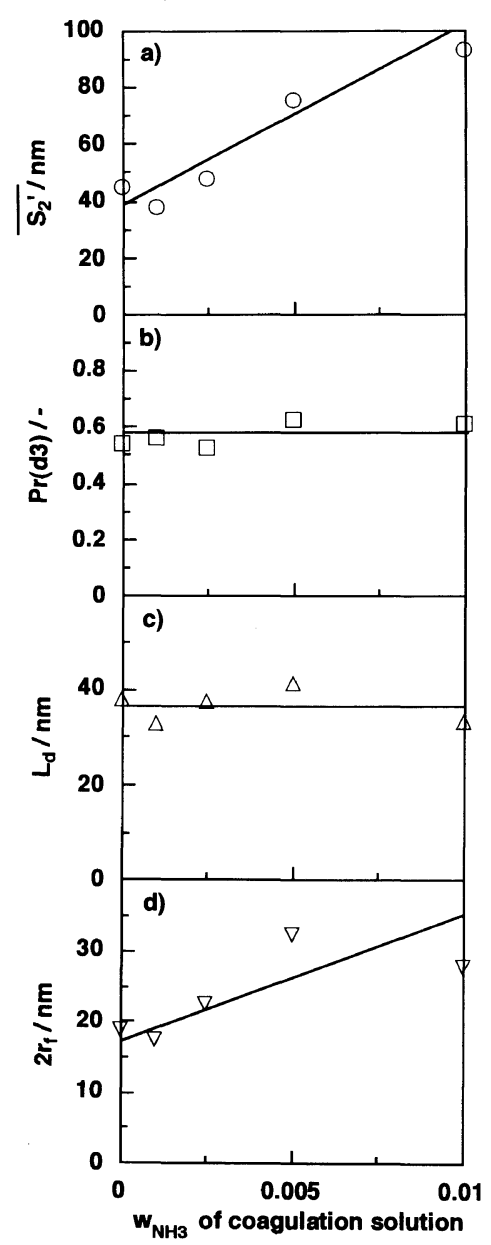

Figure 6. Effects of weight fraction of ammonia $w_{\mathrm{NH}_{3}}$ of the coagulation solution on mean radius of dry polymer particles $\overline{S_{2}^{\prime}}(\mathrm{a})$, porosity of membranes $\operatorname{Pr}\left(\mathrm{d}_{3}\right)$ (b), thickness of the dry membrane $L_{\mathrm{d}}(\mathrm{c})$, and mean diameter of pores measured by the water-flow-rate method $2 r_{\mathrm{f}}$ (d): Regenerated cellulose membranes were prepared from the cuprammonium cellulose solutions by the phase separation method; cast solution, series II-3 $\left(w_{\mathrm{Cell}}=0.08 ; w_{\mathrm{NH}_{3}}=0.08 ; w_{\mathrm{Cu}}=0.029 ; w_{\mathrm{H}_{2} \mathrm{O}}=\right.$ 0.811 ); coagulation solution ( $w_{\text {Acetone }}=0.30 ; w_{\mathrm{NH}_{3}}=0.0-0.01$ ).

Polym. J., Vol. 29, No. 2, 1997 
estimated from the micrographs (not shown here) of surfaces of porous regenerated cellulose membranes prepared by immersing cuprammonium cellulose solution $\left(w_{\text {Cel1 }}=0.08\right.$; series II-3) as cast solution $\left(L_{0}=\right.$ $250 \mu \mathrm{m})$ into coagulation solution $\left(w_{\text {Acetone }}=0.30\right)$ with different $w_{\mathrm{NH}_{3}}$ (i.e., $0 \leq w_{\mathrm{NH}_{3}} \leq 0.01$ ). With an increase in $w_{\mathrm{NH}_{3}}, \overline{S_{2}^{\prime}}$ became larger, showing excellent linear proportion to $w_{\mathrm{NH}_{3}}$ of coagulation solutions.

Figure $6 \mathrm{~b}$ shows that $\operatorname{Pr}\left(\mathrm{d}_{3}\right)$ is almost constant over a whole range of $w_{\mathrm{NH}_{3}}(0-0.01)$ of coagulation solution. $L_{\mathrm{d}}$ also does not change in a range of $w_{\mathrm{NH}_{3}}$ of coagulation solution from 0 to 0.01 (Figure 6c). Accordingly, $2 r_{\mathrm{f}}$ increased with an increase in $w_{\mathrm{NH}_{3}}$ of coagulation solution as the lattice theory predicts (see, Figure 12 of ref 5).

Figure 7 shows the dependence of $\overline{S_{2}^{\prime}}, \operatorname{Pr}\left(\mathrm{d}_{3}\right), L_{\mathrm{d}}$, and $2 r_{\mathrm{f}}$ on $w_{\mathrm{NH}_{3}}$ of cast solution. Membranes were prepared under the conditions listed in Table I.

In Figure $7 \mathrm{a}, \overline{S_{2}^{\prime}}$ was estimated from their micrographs (not shown here). $\overline{S_{2}^{\prime}}$ becomes larger with an increase in $w_{\mathrm{NH}_{3}}$ of cast solution. As shown in Figure 5a, $\overline{S_{2}^{\prime}}$ was practically the same even if $w_{\text {Cell }}$ was different when $w_{\mathrm{NH}_{3}}$

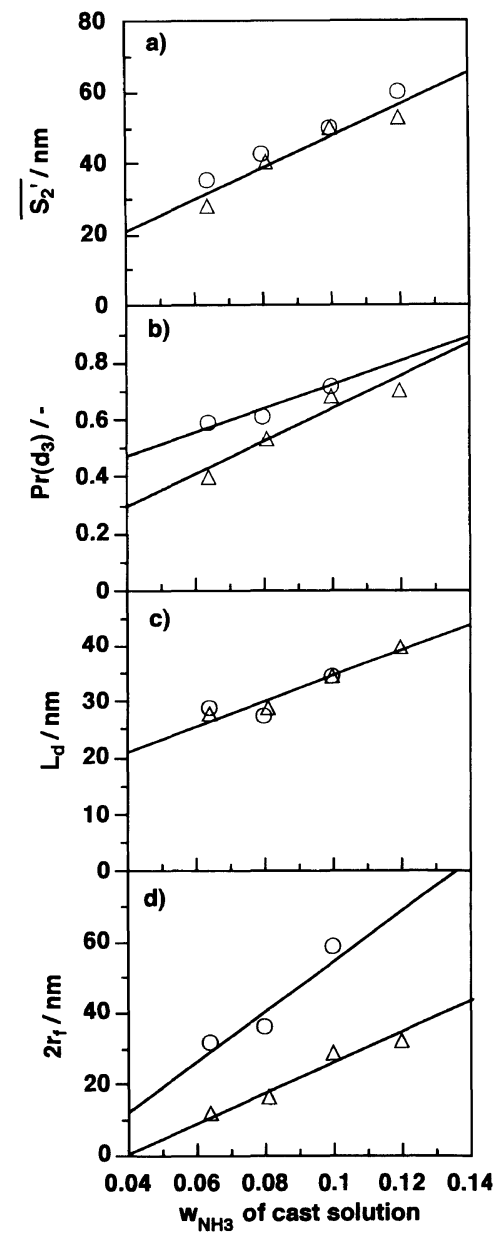

Figure 7. Effects of weight fraction of ammonia $w_{\mathrm{NH}_{3}}$ of the cast solution on mean radius of dry polymer particles $\overline{S_{2}^{\prime}}(\mathrm{a})$, porosity of membranes $\operatorname{Pr}\left(\mathrm{d}_{3}\right)$ (b), thickness of dry membrane $L_{\mathrm{d}}(\mathrm{c})$, and mean diameter of pores measured by the water-flow-rate method $2 r_{\mathrm{f}}$ (d): Regenerated cellulose membranes were prepared from cuprammonium cellulose solutions by the phase separation method; cast solutions, series III (see, Table I) (open circle); $w_{\text {Cell }}$ of the cast solution, 0.06; $w_{\mathrm{NH}_{3}}$ of the cast solution, $0.048-0.16 ; w_{\text {Acetone }}$ in coagulation solution, 0.30 . $w_{\mathrm{H}_{2} \mathrm{O}}$ in coagulation solution, 0.70 ; series IV (see, Table I) (open triangle); $w_{\text {Cell }}$ of the cast solution, $0.08 ; w_{\mathrm{NH}_{3}}$ of the cast solution, $0.064-0.12 ; w_{\text {Acetone }}$ of the coagulation solution, $0.30 . w_{\mathrm{H}_{2} \mathrm{O}}$ of the coagulation solution, 0.70 ; thickness of the cast solutions $L_{0}, 250 \mu \mathrm{m}$. of cast solutions was kept constant. It was found that $\overline{S_{2}^{\prime}}$ depended strongly on $w_{\mathrm{NH}_{3}}$ of cast solution, never depended on $w_{\text {Cell }}$ of the cast solution. Therefore, it becomes clear that the concentration of ammonia of both cast and coagulation solutions is one of the most important factors controlling the growth of cellulose secondary particles during the phase separation process of the cellulose cuprammonium/acetone/water system.

In Figure $7 \mathrm{~b}, \operatorname{Pr}\left(\mathrm{d}_{3}\right)$ also increases with $w_{\mathrm{NH}_{3}}$ of cast solution and $\operatorname{Pr}\left(\mathrm{d}_{3}\right)$ at $w_{\text {Cell }}=0.06$ was larger than that at $w_{\text {Cell }}=0.08$ in the lower $w_{\mathrm{NH}_{3}}$ region; their difference at the same $w_{\mathrm{NH}_{3}}$ value becomes significant in lower $w_{\mathrm{NH}_{3}}$ region. Figure $7 \mathrm{c}$ shows that $L_{\mathrm{d}}$ increases linearly with an increase in $w_{\mathrm{NH}_{3}}$, irrespective of $w_{\mathrm{Cell}}$.

As shown in Figure $7 \mathrm{~d}, 2 r_{\mathrm{f}}$ increases with $w_{\mathrm{NH}_{3}}$ : Note that increase of $w_{\mathrm{NH}_{3}}$ of cast solution brings about an increase in $\overline{S_{2}^{\prime}}$ (Figure $7 \mathrm{a}$ ) and $\operatorname{Pr}\left(\mathrm{d}_{3}\right)$ (Figure $7 \mathrm{~b}$ ). These experimental results agree well with the prediction of KI's lattice theory on pore size distribution $N(r)(r$, radius of pore), where $N(r)$ becomes wider and its peak shifts to a larger region of $r$ with an increase in $\operatorname{Pr}\left(\mathrm{d}_{3}\right)$, resulting in an increase in $2 r_{\mathrm{f}} .{ }^{5}$ Furthermore, the theory predicts an increase of $2 r_{\mathrm{f}}$ with an increase in $S_{2}{ }^{5}$ For example, when $S_{2}$ becomes five times larger, a range of $N(r)$ is expected to becomes five times larger, shifting to larger $r$ side (see Figure 12 in ref 5).

In higher region $(-0.14)$ of $w_{\mathrm{NH}_{3}}$ of cast solution, $\operatorname{Pr}\left(\mathrm{d}_{3}\right)$ for $w_{\text {Cell }}=0.08$ approximately coincides with that for $w_{\text {Cell }}=0.06$ (Figure $7 \mathrm{~b}$ ), but the differences of $2 r_{\mathrm{f}}$ in both cases $\left(w_{\text {Cell }}=0.08\right.$ and 0.06$)$ becomes remarkable with an increase in $w_{\mathrm{NH}_{3}}$. This can not be explained by a simple membrane model having all noncircular pores; it might be one of possibilities that pore shape might changes from noncircular (near a front surface of a membrane) to circular (inside of the membrane) in case for $w_{\text {Cell }}=0.08$ with higher $w_{\mathrm{NH}_{3}}$ of cast solution.

\section{Effect of Thickness of Cast Solution $L_{0}$ on Radius of} Secondary Particles $S_{2}^{\prime}$

Figure 8 shows the plots of thickness of solution $L_{0}$ cast on glass plate versus radius of dry secondary particles on membrane surface coagulated $\overline{S_{2}^{\prime}}$. $\overline{S_{2}^{\prime}}$ increases with an increase of $L_{0}$. This can be explained as: at coagulation

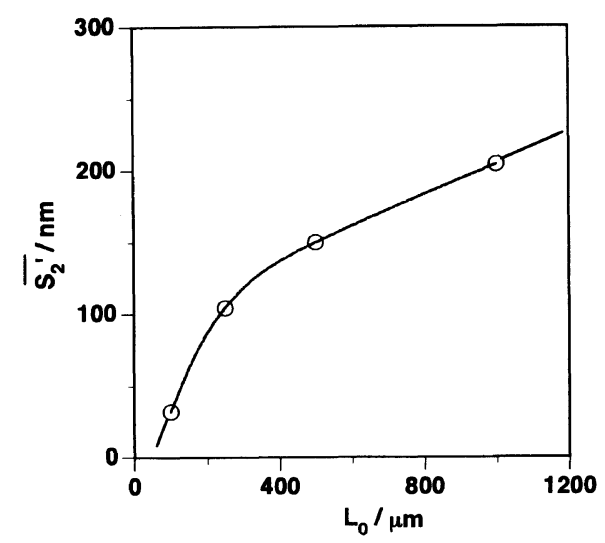

Figure 8. Plots of mean radius of dried secondary particle $\bar{S}_{2}^{\prime}$ on a front surface of the membrane against thickness of the cast solution $L_{0}: w_{\text {Cell }}($ cast solution $)=0.08 ; w_{\mathrm{NH}_{3}}($ cast solution $)=0.08 ; w_{\text {Acetone }}$ $($ coagulation solution $)=0.30 ; w_{\mathrm{NH}_{3}}($ coagulation solution $)=0 ; w_{\mathrm{H}_{2} \mathrm{O}}$ (coagulation solution $)=0.70$; coagulation temperature, $25^{\circ} \mathrm{C}$; coagulation time, $20 \mathrm{~min}$. 
step, ammonia concentration near surface of coagulated membrane is expected to decrease slowly in case of larger $L_{0}$ than in case of smaller $L_{0}$.

\section{Effect of Acetone Concentration of Coagulation Solution on $L_{g}$ and Particle Growth}

Cast solution $\left(\mathrm{I}-5 ; w_{\text {Cell }}=0.06\right)$ with thickness $L_{0}$ of $500 \mu \mathrm{m}$ was coagulated for $30 \mathrm{~min}$ in coagulation solution $\left(w_{\text {Acetone }}=0.30 ; w_{\mathrm{NH}_{3}}=0.0056 ; w_{\mathrm{H}_{2} \mathrm{O}}=0.6944\right)$ : Thickness of gel membrane $L_{\mathrm{g}}$ (step $\mathrm{h}$ in Figure 1), regenerated membrane $L_{\mathrm{rg}}$ (step i in Figure 1), wet cellulose membrane $L_{\mathrm{w}}$ and dry cellulose membranes $L_{\mathrm{d}}$ (step j in Figure 1) were $103.2 \mu \mathrm{m}, 91.7 \mu \mathrm{m}, 91.7 \mu \mathrm{m}$, and $68.8 \mu \mathrm{m}$, respectively. $L_{0}$ (step a in Figure 1) dramatically decreases when dipped into coagulation solution (steps $b-i$ in Figure 1), indicating that the polymer-rich phase formed by separation of cellulose solution contracted forming gel membrane with thickness $L_{\mathrm{g}}$ of $c a .1 / 5$ of $L_{0}$ (step h). $L_{\mathrm{g}}$ was a little larger than $L_{\mathrm{rg}}$, which was approximately equal to $L_{\mathrm{w}}$.

Figure 9a shows changes in $L_{\mathrm{g}}$ and $\overline{S_{2}^{\prime}}$ with time during coagulation step. Cast solutions $\left(w_{\text {Cell }}=0.05\right.$; code I- 6 in Table I) were coagulated to give gel membranes by immersing them in coagulation solutions $\left(w_{\text {Acetone }}=0.30\right.$; $w_{\mathrm{NH}_{3}}=0.0056$ ) for $60 \mathrm{~min}$ and change in $L_{\mathrm{g}}$ during coagulation was estimated. At an early stage of the coagulation step, the gel membranes adhered to the glass

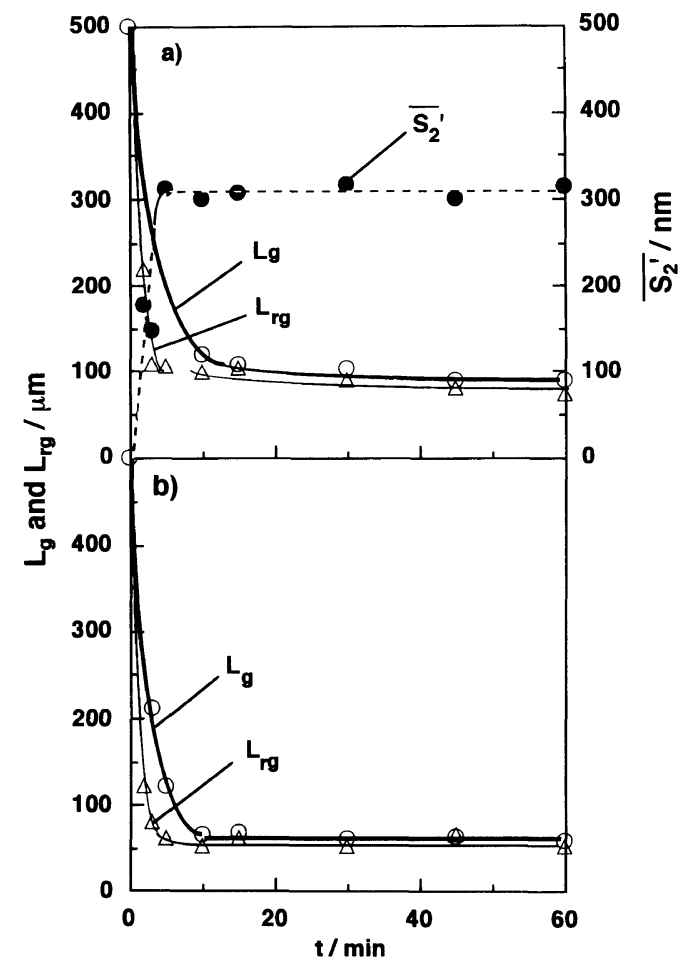

Figure 9. Changes in thickness of membrane $L$ and mean radius of cellulose particle $\overline{S_{2}^{\prime}}$ : a) Time-course changes of thickness of gel membrane $L_{\mathrm{g}}$, thickness of wet regenerated wet membrane $L_{\mathrm{rg}}$, and mean radius of dry cellulose particles $\overline{S_{2}^{\prime}} ; w_{\text {Cell }}, 0.05$; cast solution was prepared by series I (see, Table I); $L_{\mathrm{rg}}$, thickness of wet cellulose membranes regenerated with $2 \mathrm{wt} \%$ aqueous sulfuric acid after given coagulation time; thickness of the cast solution $L_{0}, 500 \mu \mathrm{m}$; weight compositions of the coagulation solution, $w_{\text {Acetone }} / w_{\mathrm{NH}_{3}} / w_{\mathrm{H}_{2} \mathrm{O}}, 0.30 /$ $0.0056 / 0.6944$; open circle, $L_{\mathrm{g}}$; closed circle, $L_{\mathrm{rg}}$; open triangle, $\bar{S}_{2}^{\prime} ;$ b) Time-course changes of $L_{\mathrm{g}}$ and $L_{\mathrm{rg}}$; weight compositions of the coagulation solution, $w_{\text {Acetone }} / w_{\mathrm{NH}_{3}} / w_{\mathrm{H}_{2} \mathrm{O}}, 0.50 / 0.0056 / 0.4944$; open circle, $L_{\mathrm{g}}$; closed circle, $L_{\mathrm{rg}}$. plates, and they were too soft to measure $L_{\mathrm{g}}$ by pressing the gel membrane perpendicularly to its surface without any deformation of the membrane. Thickness of the wet membrane after regenerated by dipping in aqueous sulfuric acid $(2 \mathrm{wt} \%) L_{\mathrm{rg}}$ was also measured. $L_{\mathrm{g}}$ is larger than $L_{\mathrm{rg}}$ till $10 \mathrm{~min}$ from the beginning, and the difference between $L_{\mathrm{g}}$ and $L_{\mathrm{rg}}$ becomes smaller, reaching $L_{\mathrm{g}} \approx L_{\mathrm{rg}}$ after $15 \mathrm{~min}$ from the beginning of coagulation. $L_{\mathrm{g}}$ decreases very rapidly at the early stage of coagulation $(0<t<5 \mathrm{~min})$, resulting in a decrease of thickness of the cast solution and an increase in $w_{\text {Cell }}$. For this duration, two-phase separation may occur on the top surface of the cast solution and polymer particles on the surface grow rapidly, reaching to asymptotic value at $t=5 \mathrm{~min}$. It can be considered that the contraction of thin layers may occur in a range of $t>5 \mathrm{~min}$, where the gradual decrease in $L_{\mathrm{g}}$ is observed. Computer simulation demonstrated that the decrease in thickness by collapse of hypothetical layers during coagulation corresponds to the decrease in apparent phase volume ratio $R_{\mathrm{A}} \cdot{ }^{6}$

$L_{\mathrm{g}}$ at $w_{\text {Acetone }}=0.50$ (Figure $9 \mathrm{~b}$ ) diminishes more rapidly at $t<3 \mathrm{~min}$, because water can move faster from the cast solution to the coagulation solution. At $3<t<$ $10 \mathrm{~min}, L_{\mathrm{g}}$ decreases gradually and it reaches to plateau value which is much smaller than that obtained in case of $w_{\text {Acetone }}=0.30$ (Figure $9 \mathrm{a}$ ).

As Figures $4 \mathrm{~g}-1$ show, cross-sections of pore particles (i.e., pore cells) turned flat in cases of $w_{\text {Acetone }}$ of coagulation solutions $=0.35$ and 0.40 . The decrease in thickness at $3<t<10 \mathrm{~min}$ can be regarded as due to the deformation of pore particles from spheres to flat plates.

Effect of Acetone Concentration in Coagulation Solution on Thickness of Membrane, Porosity $\operatorname{Pr}\left(\mathrm{d}_{3}\right)$, Mean Pore Size $2 r_{\mathrm{f}}$, and Tensile Strength TS of Membrane

Figure 10a shows the plots of thickness $L_{\mathrm{d}}$ of dry membrane, prepared from cellulose solutions of $w_{\text {Cell }}=$ $0.05-0.07$ (I-4 to I-6 in Table I) against $w_{\text {Acetone }}$ of coagulation solution. In the range of $w_{\text {Acetone }}=0.25$ $0.40, L_{\mathrm{d}}$ decreases linearly with $w_{\text {Acetone }}$. This can be explained as follows: water molecules move faster than acetone molecules from the cellulose solution to the coagulation solution across the interface between them in case of $w_{\text {Acetone }}$ of coagulation solution $>0.25$.

Figure $10 \mathrm{~b}$ shows the plots of $\operatorname{Pr}\left(\mathrm{d}_{3}\right)$ against $w_{\text {Acetone }}$ of coagulation solution. With an increase in $w_{\text {Acetone }}$, $\operatorname{Pr}\left(\mathrm{d}_{3}\right)$ decreases linearly in cases of $w_{\text {Cell }}=0.05,0.06$, and 0.07 . These facts agree well with the relation between $w_{\text {Acetone }}$ of coagulation solution and $L_{\mathrm{d}}$ (Figure 10a). In lower region of $w_{\text {Acetone }}, \operatorname{Pr}\left(\mathrm{d}_{3}\right)$ is larger when $w_{\text {Cell }}$ is lower, but this tendency becomes, more or less, vague in the higher $w_{\text {Acetone }}$ region, i.e., $w_{\text {Cell }}$ dependence of $\operatorname{Pr}\left(\mathrm{d}_{3}\right)$ becomes smaller. Comparison of these results with the relations between $w_{\text {Cell }}$ and $\operatorname{Pr}\left(\mathrm{d}_{3}\right)$ (Figure 5c) leads us to conclusion that $\operatorname{Pr}\left(\mathrm{d}_{3}\right)$ depends more remarkably on $w_{\text {Acetone }}$ in coagulation solution than $w_{\text {Cell }}$.

Figure $10 \mathrm{c}$ shows the plots of $2 r_{\mathrm{f}}$ versus $w_{\text {Acetone }}$ of coagulation solution. In regions $w_{\text {Acetone }}<0.35,2 r_{\mathrm{f}}$ decreases in reversely linear relation to $w_{\text {Acetone }}$, whereas in the range of $w_{\text {Acetone }}>0.35,2 r_{\mathrm{f}}$ is kept almost constant. The dramatic change in the $w_{\text {Acetone }}$ dependence of $2 r_{\mathrm{f}}$ at $w_{\text {Acetone }} \approx 0.35$ corresponds closely to the change in pore shape from noncircular to circular (Figure 2). The theory 


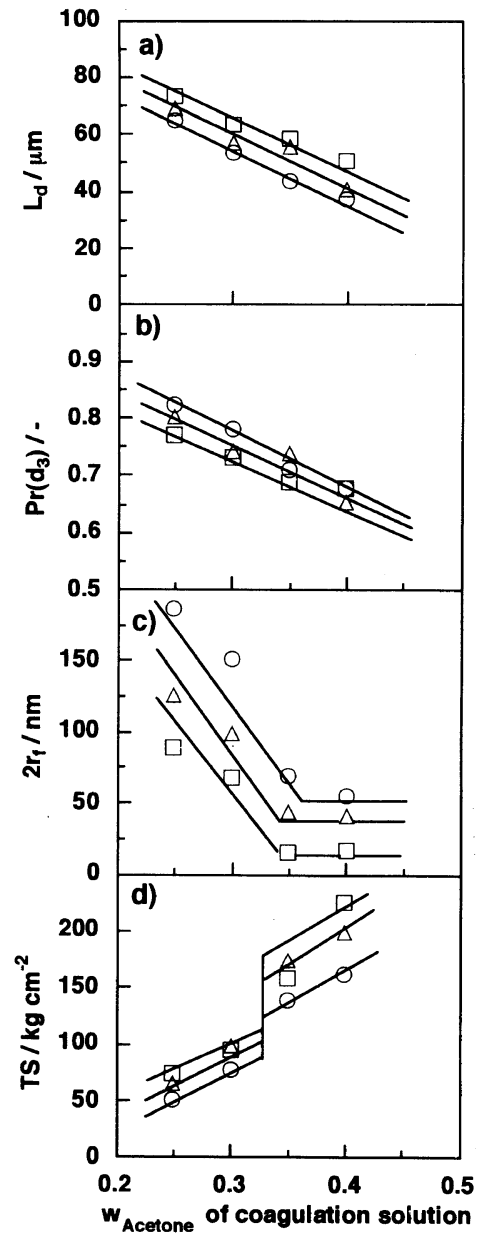

Figure 10. Effects of weight fraction of acetone $w_{\text {Acetone }}$ of the coagulation solution on thickness of dry membrane $L_{\mathrm{d}}(\mathrm{a})$, porosity $\operatorname{Pr}\left(\mathrm{d}_{3}\right)$ (b), mean radius of pores measured by water-flow-rate method $2 r_{\mathrm{f}}(\mathrm{c})$, and tensile strength $T S$ of the membranes (d): Cast solutions were prepared from series I (see, Table I); thickness of the cast solution $L_{0}$, $500 \mu \mathrm{m}$; compositions of the coagulation solution $\left(w_{\text {Acetone }} / w_{\mathrm{NH}_{3}} / w_{\mathrm{H}_{2} \mathrm{O}}\right)$, (0.25/0.0056/0.7444); (0.30/0.0056/0.6944); (0.35/0.0056/0.6444); (0.4/ $0.0056 / 0.5944)$; open circle, $w_{\text {Ceil }}$ (cast solution) $=0.05$; open triangle, $w_{\text {Cell }}$ (cast solution $)=0.06$; open square, $w_{\text {Cell }}$ (cast solution $)=0.07$.

explains that pore shape depends on the polymer concentration, relative to the critical solution point for polymer/solvent system. ${ }^{3}$

Figure 10d shows the dependence of tensile strength $T S$ of the membranes on $w_{\text {Acetone }}$ of the coagulation solution. Generally, with an increase in $w_{\text {Acetone }}, T S$ increases and in particular, when $w_{\text {Acetone }}$ increases from 0.30 to 0.35 , TS increases suddenly by $1.7-1.8$ times as compared with that estimated at $w_{\text {Acetone }}=0.30$. Electron microscopic observation of membrane surface (Figure 2) shows that at the boundary between 0.30 and 0.35 in $w_{\text {Acetone }}$, membrane structure changes from noncircular pores of connecting polymer particles to circular pores consisting of flat sheets of continuous polymer-rich phase. $T S$ of the latter is significantly larger than that of the former.

\section{CONCLUSIONS}

1) Pore shape of membranes depends on acetone concentration $w_{\text {Acetone }}$ of the system, and $w_{\text {Acetone }}$ of coagulation solution is one of the most important factors determining phase separation characteristics such as two phase volume ratio $R$ and the compositions at phase separation points (Figure 2).

2) The density of dried polymer particle $d_{\mathrm{P}}^{\prime}$ has a tendency to become larger when $w_{\text {Cell }}$ is higher in cast solution (Figure 5).

3) Ammonia concentration $w_{\mathrm{NH}_{3}}$ in the system of cellulose cuprammonium/acetone/water dominates the size of the cellulose secondary particles. When $w_{\mathrm{NH}_{3}}$ of coagulation solutions or of cast cellulose solutions is higher, the membranes are constituted of larger cellulose particles (Figures 6 and 7).

4) Membranes consisting of larger secondary particles have larger mean pore size, and this fact agrees well with the prediction by KI's lattice theory on pore size distribution (Figures 6 and 7).

5) Change in pore shape of membrane surface from noncircular to circular with the casting conditions corresponds well to drastic changes in $2 r_{\mathrm{f}}$ and tensile strength $T S$ of the membrane (Figures 2 and 10).

\section{REFERENCES}

1. K. Kamide and S. Manabe, "Material Science of Synthetic Membranes," ACS Symposium Series, No. 269, D. R. Lloyd, Ed., American Chemical Society, Washington, D.C., 1985, pp $197-228$.

2. K. Kamide, "Thermodynamics of Polymer Solutions; Phase Equilibria and Critical Phenomena," Polymer Science Library 9, A. D. Jenkins, Ed., Elsevier Science Publishers B. V., Amsterdam, The Netherlands, 1990, Chapter 6.

3. K. Kamide, H. Iijima, and S. Matsuda, Polym. J., 25, 1113 (1993).

4. K. Kamide, H. Iijima, and H. Shirataki, Polym. J., 26, 21 (1994).

5. H. Iijima, S. Matsuda, and K. Kamide, Polym. J., 26, 439(1994).

6. K. Kamide, H. Iijima, and A. Kataoka, Polym. J., 26, 623 (1994).

7. H. Iijima, A. Kataoka, and K. Kamide, Polym. J., 27, 1033 (1995).

8. See, for example, H. D. Williams, U. S. Patent 3,236,669 (1966); C. C. McCorsley, III and J. K. Varga, U. S. Patent 4,142,913 (1979); A. F. Turbak, A. El-Kafrawy, F. W. Snyder, Jr., and A. B. Auerbach, U. S. Patent 4,302,252 (1981); I. Miyamoto, Y. Matsuoka, T. Matsui, M. Saito, and K. Okajima, Polym. J., 28, 276 (1996).

9. E. Schweizer, J. Pract. Chem., 72, 109 (1857).

10. See, for example, E. Murakami, M. Matsui, R. Hasegawa, A. Asanuma, and S. Jindai, Japanese Patent 1099603 (1982).

11. See, for example, G. Dunweg, Japanese Patent 1579340 (1990); British Patent 2086798 (1984).

12. M. Iwata, S. Manabe, and M. Inoue, Japanese Patent 1439049 (1988); Japanese Patent 1434154 (1988); Japanese Patent 1473266 (1988); U. S. Patent 4,581,140 (1986); U. S. Patent 4,604,326 (1986); U. S. Patent 4,822,540 (1989).

13. W. Brown and R. Wikstrom, Eur. Polym. J., 1, 1 (1965).

14. J. Brandrup and E. H. Immergut, Ed., "Polymer Handbook," 3rd ed, John Wiley \& Sons, Inc., New York, N.Y., 1989, p V-122.

15. See, for example, R. E. Kesting, "Synthetic Polymer Membranes," 2nd ed, John Wiley \& Sons, Inc., New York, N.Y., 1985, p 49.

16. "Kagaku-Binran, Kiso-Hen (Handbook of Chemistry, Fundamentals)," 3rd ed, Maruzen, Tokyo, Japan, 1984, p II-14.

17. S. Manabe, Y. Kamata, H. Iijima, and K. Kamide, Polym. J., 19, 391 (1987). 